\title{
Achieving Communicative Equivalence: Space-time Text Organization Peculiarities in Stream of Consciousness Novels of James Joyce in German and Russian Translations
}

\author{
Alexandra Milostivaya ${ }^{1} \&$ Irina Makhova ${ }^{2}$ \\ ${ }^{1}$ Associate Professor at the North-Caucasus Federal University (Russia). ORCID: oooo- \\ ooo1-5052-2622. Email: xyscha@mail.ru \\ ${ }^{2}$ Associate Professor at the Stavropol State Agrarian University (Russia). Email: \\ zheltova.ira71@mail.ru
}

Received February 13, 2017; Revised April 3, 2017; Accepted April 8, 2017; Published May 7, 2017.

\begin{abstract}
The article analyzes different types of space-time organization patterns in the Stream of Consciousness texts (SCT) to determine communicative equivalence in translation. The study focuses on two novels by J. Joyce - Ulysses and Finnegans Wake, and their German and Russian translations. The conclusion can be made that there are two types of patterns realizing stream of consciousness technique in J. Joyce's works: SCT with space-time hyperlinearity and SCT with chaotic-cyclic dominant, which can be conveyed in a communicatively equivalent way in target languages (TLs) with the reference to different translation strategies. Literal hyperlinear equivalents prevail in translation of first type SCT (equivalents or transcribed source language (SL) lexemes), while the translation of second type SCT features hermeneutic reflection of a translator actualized in the search of the most adequate way of form generation which conveys multidimensional sense of the author's intentions to maximum extent.
\end{abstract}

Keywords: communicative equivalence of translation, stream of consciousness text, J. Joyce's novel Ulysses, J. Joyce's novel Finnegans Wake, space-time literary text organization

\section{Introduction}

The topicality of studies examining peculiar features of the translation of the Stream of Consciousness texts (SCT) rises from the fact that despite numerous research works on translation equivalence in different types of texts so far, there is no conception of SCT translation equivalence, as well as other types of modernist texts. Besides, being the heritage of world literature, SCT represents a phenomenon, which is unfamiliar to German and Russian cultural traditions as the most well-known writers who employed this literary technique were English and French native speakers.

The term "translation equivalence" used in the study is considered one of the basic notions in modern translatology not without a reason. The analysis of its essence is given in many works of leading translation theory specialists (Catford, 1965; Kade, 1968; Rei $\beta$, 1976; Koller, 1979; Toury, 1980; Nida \& Taber, 1982; Komissarov, 1987; Vinogradov, 2001; Breus, 2003; Pym, 2007 et al.). English translation scholar J. C. Catford defines translation as the substitution of text material in

(c) AesthetixMS 2016. This Open Access article is published under a Creative Commons Attribution Non-Commercial 4.0 International License (http://creativecommons.org/licenses/by-nc/4.o/), which permits non-commercial re-use, distribution, and reproduction in any medium, provided the original work is properly cited. For citation use the DOI. For commercial re-use, please contact editor@rupkatha.com. 
one language (SL) by equivalent text material in another one (TL) $(1965, \mathrm{p} .27)$. Thus it is assumed that "a source text and a translation can share the same value (equivalence) on some level, and that this assumed sameness is what distinguishes translations from all other kinds of texts" (Pym, 2007, p. 272).

In a similar way American researchers E. A. Nida and Ch. Taber claim that translation is about "reproducing in the receptor language the closest natural equivalent of the source-language message, first in terms of meaning and secondly in terms of style" (1982, p. 12). The notion "equivalence" acquires axiological shade of meaning, i.e. a "good" or a "correct" translation is only the equivalent one.

Since equivalence is the condition of translation, the aim is to determine this condition specifying its essence and what is supposed to be preserved in translation. Thus, O. Kade defined translation equivalence as sign invariance of plane of content and plane of expression in ST and TT. At the same time, preserving denotative invariance was admitted as a minimum indispensable condition, while significative meaning, plane of expression invariants and pragmatic invariants were claimed as optional depending on the character and the purpose of TT (Kade, 1968).

An alternative point of view on translation equivalence is fostered in works developed by $\mathrm{K}$ Reis within Scopos-theory. TT and ST equivalence in text and functional aspects is subdominant and is treated as a special case incapable of determining the notion "translation" on the whole. Even less prominence is given to the account of ST language peculiarities, those "intralingual instructions" which once were treated as a part of requirements to translation. The main and almost the only criterion of TT assessment is claimed to be "the compliance with the aim it was supposed to attain" (Reis, 1976, p. 97).

In modern Russian translation theory the term "translation adequacy" correlates with the notion "translation equivalence". In fact, some linguists match these two. V. S. Vinogradov defines translation equivalence as "preserving relative parity of content, sense, semantic, stylistic and functional-communicative information" (Vinogradov, 2001, p. 18), and explicitly claims equal significance of translation "adequacy" and "equivalence". Introducing the term of "communicative-functional equivalence" of ST and TT as the equivalence of communicative effects on the recipient, the linguist virtually eliminates the distinction between the opposed notions.

E. V. Breus, on the contrary, sharply differentiates translation adequacy and equivalence.

Complete equivalence presupposes comprehensive conveyance of all ST communicative parameters. Adequacy is based on objective translation practice, which often does not allow for absolute conveyance of ST entire communicative content. Thus, in many case the decision made by the translator is of compromise. It is said, the translation demands sacrifices. It is to be interpreted in a sense that in the process of translation a translator has to make sacrifices for the sake of conveying of the most relevant content of ST (its communicative guidelines and communicative effect) (Breus, 2003, p. 18).

Translation features the substitution of the signs of one language by the signs of another one as well, but it is aimed at creating equivalent text in TT culture. In this case, the main point is the analysis of communicative situation, i.e. the purpose, subject of communication, the addresser, the addressee, the communities represented by them, means of communication and conditions of information communication. The change in communicative situation leads to changes in TT.

In this study, we share translation theories, which do not delimit translation equivalence 
and adequacy. We interpret communicative translation of TT foremost as the focus on translation process, conveying author's communicative intention even at the expense of preserving full communicative-functional content of ST.

We proceed with specifying peculiarities of SCT under consideration, which are relevant in achieving communicative equivalence of translation. Traditionally SCT is defined as "a technique that represents the movement of thoughts and impressions as they flow through the mind" (Childs, 2000, p. 211). S. Chatman treats SCT as a narrative technique, which "contains the arrangement of semantic elements according to the principle of free association" (Chatman, 1980, p.189). Besides, critics underline that when creating SCT a writer employs linear language but it is accompanied by "the effect of flowing in three dimensions of space through time, of containing not only language, but also a variety of images and orientations, and of functioning at several levels of abstraction" (Steinberg, 1983, p. 41).

It accounts for relevance of linearization in space-time text structure while producing SCT. In Russian language studies the process correlates with such literary text category as continuum. The term "continuum" denotes continuous development of the information chain, i.e. "nonsegmented flow of movement in time and space" (Galperin, 2006, p. 87). Most generally continuum as a text category can be presented as a certain sequence of facts and events unfolding in time and space. The researcher of a literary text faces the question of borders between real world and the one created by the author of a literary work, as well as quantity and quality parameters of continuum represented in different types of texts. Following M. Bakhtin it seems reasonable to delimit in a literary text space-time dimensions which correlate with "author character" and "character 1 - character 2" continua. In SCT there is transposition of "character 1 character 2" continuum into "author - character" continuum which is not marked lexically, graphically or grammatically.

The variety of representation of continuum system in SCT preconditions the peculiarities of its perception. The main strategy of activity seems to be conversion from the language of thought (i.e. inner sense code of the author and the character) into literary language. This conversion should be transparent in the process of reading SCT as TT, which appears to be the main condition of achieving communicative equivalence in SCT translation.

\section{Materials and Research Methods}

The main research method to study space and time organization of SCT as the determinant of communicative equivalence of German and Russian versions of J. Joyce's novels was the comparative analysis of ST written by J. Joyce and the translated versions. Apart from the comparative method we also applied the descriptive one in all variations (observation, generalization, interpretation and classification), which was supplemented by component and distribution hermeneutic analysis to decode and interpret the writer's intentions in SCT in the light of its space and time organization peculiarities.

In particular, the study is based on Ulysses and Finnegans Wake - works by J. Joyce, as well as German and Russian versions of the novels. Ulysses and Finnegans Wake are among the central novels in world literature written in SC technique.

Ulysses was devised by J. Joyce as a modern "Odyssey". Odysseus was Leopold Bloom, an advertising canvasser from Dublin. His drama comes from rather ordinary life experience but Bloom's fate, along with the ones of his wife Molly, a cabaret singer, and of Stephen Dedalus - an 
unfortunate writer - seem to be of equal interest to the fates of mythological prototypes Odysseus, Penelope and Telemachus. The time and the history changed the exterior - clothes, everyday life, behavior and the language. Still the drama of souls and turbulent passions are depicted with their original intensity, the myth is exposed to modern life. There is no plot in Ulysses in its traditional sense. It features acute attention to the subjective, hidden in psyche and consciousness of an individual. Joyce assumes that consciousness is a stream, a flow in which thoughts, sensations, unexpected associations abrupt each other continuously and intertwine in a quaint and irrational way. Thus, the narration is to be interpreted as the stream of characters' consciousness. The action of the novel (over 8oo pages!) takes place in the course of one day 16 June 1904. This implies much detail in depiction of all events. Ulysses was created in the time of modernist literature (the work on the novel dates back to 1914 - 1921). In line with the requirements of literary fashion of those times, Ulysses was not addressed to a mass reader. Joyce is known to be aspired to some ideal readers who would be ready to leave everyday routine and live the life reconstructed in Ulysses. It is highly important and should be taken into account in translation process in order to avoid any simplification in TL.

The study is based on two Russian versions of Ulysses: translation of Viktor Khinkis and Sergey_Khoruzhii (Joyce, 2004), first published in 1989, and a later version by Sergey Makhov (Joyce, 2007) published in 2007. German versions of Ulysses employed in the study were made by Georg Goyert (Joyce, 1966) and Hans Wollschläger (Joyce, 2006), originally published in 1956 and 1975 respectively.

Finnegans Wake by Joyce is also written in SC technique. The writer had been working on it for 16 years (the work started on 10 March 1923). The novel was published in his lifetime in 1939 and evoked vastly ambiguous reaction in literary community. Like Ulysses it is aimed at ideal readers and made of a continuous string of multilingual puns and neologisms, which makes it poorly comprehensible. The study focuses on German versions of parts from Joyce's Finnegans Wake made by Harald Beck, Kurt Jauslin, Wolfgang Schrödter and Friedhelm Ratjen, created in 1980 and published in collected works Finnegans Wake Deutsch. Gesammlte Annäherungen (Joyce, 1989). In Russian there is a version of selected passages by Anri Volokhonsky (Joyce, 2000a), published in 2000.

\section{Analysis}

Now let us have a look at some specific features of SCT space-time organization as the determinant of communicative equivalence of German and Russian versions of Joyce's novels.

The observations reveal that the first SCT type is characterized by space-time hyperlinearity. The author of the text tends to avoid in speech any discreteness viewed by him as thinking. With this purpose, he renounces graphic marking of direct speech. The excerpt below features the above-mentioned manner of presentation in Ulysses by J. Joyce:

Am I going to aunt Sara's or not? My consubstantial father's voice (traditional text will feature the author's speech, which introduces the direct speech of the character's father A.M.). Did you see anything of your artist brother Stephen lately? No? Sure he's not down in Strasburg terrace with his aunt Sally? Couldn't fly a bit higher than that, eh? And and and and tell us Stephen, how is uncle Si? O weeping God, the the things I married into... And skeweyed Walter sirring his father, no less. Sir. Yes, Sir. No Sir (the two final remarks convey Stephen's thoughts rather than his father's words. - A.M.) (20oob, p. 47). 
The given passages do not feature any direct speech markers. To preserve communicative equivalence they are supposed to be omitted in TT as continuous speech-thought flow is relevant for the author and preconditions the absence of direct speech and author's speech markers:

Gehe ich nun zu Tante Sarah oder nicht? Meines consubstantionellen Vaters Stimme. Hörtest du nicht kürzlich von deinem Künstler Bruder Stephan? Nein? Sicher, dass er nicht unten in Strasburg terrace bei seiner Tante Sally ist? Konnte er den nicht ein wenig höher fliegen, was? Und und und und, Stephan, erzähle uns doch, wie es Onkel Si geht. O, drucksender Herrgott, wohin bin ich geraten?.. Und der schielende Walter, der seinen Vater immer herrzt, immer nur so. Herr. Ja, Herr. Nein, Herr (Joyce, 1966, p. 46 - 47).

Geh ich nun eigentlich zu Tante Sara oder nicht? Meines konsubstantionellen Vaters Stimme. Hast du in der letzten Zeit mal was von deinem Künstler-Bruder gesehen? Nein? Ob er nicht vielleichtin Strasburg Terrace ist bei seiner Tante Sally? Noch ein bißchen höher konnt' er wohl nicht fliegen, was? Und und und und sag doch mal, Stephen, wie geht's Onkel Si? O du mein schluchzender Herrgott, in was hab' ich da blo $\beta$ reingeheiratet!.. Und der schieläugige Walter nicht minder, dermeinen Ollen permanent umsirrt. Sir. Jawohl, sir. Nein, sir (Joyce, 2006, p. 53).

Idti k tete Sjere ili net? Golos moego edinosushhnogo otca. Tebe ne popadalsja brat tvoj, hudozhnik Stiven? A ty ne dumaesh', chto on u svoej tetushki Salli na Strasburg-terras? Ne mog, chto li, zaletet' povyshe? A-a-a skazhi-ka nam Stiven, kak pozhivaet djadjushka Saj? Jeto slezy bozh'i, moja rodnja po zhene!... A kosoglazyj Uolter papashu velichaet ne inache kak sjerom. Da, sjer. Net, sjer (Joyce, 2004, p. 42).

Zagljanut' k tjote Sare ili net? Glas moego edinosushhnogo otca. Tebe ne popadalsja bratec tvoj, hudozhnik Stiven? Net? On tochno ne u tjotushki Salli na Strasburgskoj ulice? Povyshe-to zanestis' ne sladil? I i i i skazhi nam, Stiven, kak djadjushka Saj? Moja rodnja po zhene ... A kosoglazyj Uolter papashu velichaet ne inache kak sudarem. Da, sudar'. Net, sudar' (Joyce, 2007, p. 37).

As we can observe in translated passages, equivalent translation is impossible unless iterating elements are conveyed, since the intensity of some feature and relevance of the phenomenon for the author of this type of text preconditions by the number of iterations of a certain word.

Linear structured SCT is characterized by non-segmented narration expressed through omission of punctuation marks and paragraph indentions associated with thought and message completeness. As fluency is relevant for SCT the author leaves out this type of extensional pragmatic segmentation. Presumably, it is reasonable to abandon segmentation into paragraphs in order to achieve communicative equivalence, since the author's and the translator's communicative intentions should coincide. Punctuation rules in English allow omission of punctuation marks between the main and the subordinate clause, and in case of introductory words. German and Russian punctuation rules do not precondition these options; thus we assume it is reasonable to break TL norms to achieve communicative equivalence. Linear and nonsegmented narration can be preserved in German and Russian through the omission of commas (as we can observe in the passage from Ulysses) as commas pose obstacles to SC and limit communicative fragments:

I suppose he was glad to get shut of her and her dog smelling my fur and always edging to get up under my petticoats especially then still I like that in him polite to the old woman like that and waiters... (Joyce, 200ob, p. 872). 
Ich glaube erwar froh dass er sie los wurde und ihr Hund roch immer nach meinem Pelz und wollte immer unter die Röcke besonders dann aber ich mag das gerne an ihm immer höfflich zu so alten Frauen und auch zu Kellnern...(Joyce, 1966, p. 761).

Ich wei $\beta$ nicht weil der nicht heilfroh war wie er abhauen konnte von ihr und ihr Hund der andauernd an meinem Pelz am schnüffeln war und mire wig unter die Röcke wollte besonders wenn ich meine naja trotzdem irgendwie mag ich das an ihm wie er so höfflich ist zu alten Frauen und zu Kellnern... (Joyce, 2006, p. 915).

Dumaju tot schastliv byl ot nee izbavit'sja a ee pes vse obnjuhival moju shubu i norovil pod jubku zabrat'sja osobenno togda no pozhaluj mne nravitsja v nem takaja delikatnost' so staruhami i prislugoj... (Joyce, 2004, p. 728).

Tot nebos' rad by ot nej izbavit'sja psina ejo vsjo obnjuhival moju lohmatku vechno norovja pod jubku zabrat'sja osobenno $\mathrm{v}$ technye dni a vsjo zhe mne $\mathrm{v}$ njom nravitsja takaja vot vezhlivost' so staruhami da s prislugoj... (Joyce, 2007, p. 649).

We can see that linear structured SCT is characterized by distant forms of cohesion. Thus, the above-mentioned contexts contrast two time planes: Molly's thoughts about relations between her husband Leopold Bloom and his mistress, i.e. non-temporal plane of narration; and the dog's actions, i.e. a particular moment. The second temporal plane interrupts the first one, thus creating discontinuous sense unities. Another typical example of linear structured SCT "character 1 character 2" continuum is "Penelope" chapter in Ulysses. The text fragment contains 40 pages and 8 (!) hypersentences featuring the above-mentioned model.

The second SCT form in modernism is the text with traditional time-space structure extended, unlike a realistic one, by occasional words, intertextual passages and onomatopoeic elements. This narration technique provides "literal translation" of character's thinking, which is deprived of extensiveness typical of the first type.

The combinations used to imitate characters' thinking can be very complex, aimed at the ideal reader. As an American researcher R. Mc Hugh (1991) claims there are about 6o languages and jargons in Finnegans Wake by J. Joyce. The play techniques are actualized by timespace means as well. The mere possibility of text beginning and ending is presented as disputable: imitating the structure of G. Vico's historical process cyclic nature theory J. Joyce cuts short the final phase of the novel by "the" article: "A way a lone a last a loved a long the..." (Joyce, 2000, p. 628). The beginning of the novel features the missing part of the sentence: "riverrun, past Eve and Adam's, from swerve of shore to bend a bay, brings us by commodius vicus of recirculation back to Howth Casle and Environs" (Joyce, 2000, p. 3), symbolizing the idea of universal cyclical nature.

To preserve equivalence a translator makes significant modifications; still many passages in this type of text are untranslatable. For instance, German versions of passages from Finnegans Wake by J. Joyce published in collected works and edited by R. Reichert and F. Senn are more of rendering than equivalent translation in TL. The same concerns the Russian version of the novel, which is admitted by A. Volokhonsky who called his work a fragmentary sentence experience in Russian letters.

This type of SCT often contains onomatopoeic elements with no analogues in TL. Most remarkable in this regard are well-known hundred-letter words in Finnegans Wake. Let us consider one of a kind given on the first pages and describing the process of Tim Finnegan's falling:

The fall 
(bababadalgharaghtakamminarronkonnbronntonnerronntuonnthunntrovarrhounawntooh oohoooordenenthurnuk!) of a once wallstrait oldparr is retaled early in bed... (Joyce, 2000, p. 3).

Trying to imitate the falling effect translators transcribe this onomatopoeic element in German and Russian, which seems the only option to render the passage by TL means:

Der fall

(bababadalgharaghtakamminarronkonnbronntonnerronntuonnthunntrovarrhounawntooh oohoooordenenthurnuk!) eines ehmals wallstraiten oppars wird auf und rumgeschwätzt früh im bett...(Joyce, 1989, p. 27).

Padenie

(bababadalgaragtakamminarronnkonnbronntonnerronntuonntanntrovarrounaunskauntu huhurdenenternak!) prezhde prjamogo kak stolb smorchka pereskazyvaetsja poutru v posteli ... (Joyce, 200oa, p. 8).

Onomatopoeic elements are actualized in SCT with linear structured continuum as well, though their frequency is lower. See a typical example from Ulysses: "...his face clean shaven Frseeeeeeeeeeeeeeeeeeeefrong...” (Joyce, 2000b, p. 904). - “...sein glattrasiertes Gesicht Friiiiiiiiiiiiiiiiiiiiiifrong...” (Joyce, 1966, p. 790). - “...sein Gesicht noch von mir sauber rasiert Frsiiiiiiiiiiiiiiiiiiiiifrong...” (Joyce, 2006, p. 954). - “...ego lico vsegda chisto vybrit ffiiiiiiiiiiiiiiiiiiiiiiiiiuuff...” (Joyce, 2004, p. 755). - “...ego lico gladko vybritoe tutuuuuuuuuuuuuuuuuuuuuuutuuuuuuuuuuuuu ..." (Joyce, 2007, p. 673).

Here an onomatopoeic word is the sound of a shaver, which adds demonstrative effect to communicative situation and slows down the events in time. We assume that this phonetic device can be conveyed in an equivalent way by any combination of TL sounds associated with the phenomenon described. The passage given below features onomatopoeic elements compensated in a different part of the speech chain: "...train far away pianissimo eeeeeee one more song..." (Joyce, 200ob, p. 906). - “...jetot poezd pianissimo fiiiii eshhe odna fesnja...” (Joyce, 2004, p. 756). - “...poezd v dal'nej dali ochen' ochen' tihohon'ko fffffffff eshhjo odna pesenka..." (Joyce, 2007, p. $674)$.

Train horn is expressed not only in interjection " fiiiii" / "fffffffff" but in lexemes "pianissimo" / "tiho" modified in reduplicated form " tihohon'ko" or "song" / "pesnja” in "fesnja”.

As we mentioned, individual neologisms based on wordplay and subjective associations are characteristic of second type SCT. As a typical example, let us analyze the first passage from Finnegans Wake:

riverrun, past Eve and Adam's, from swerve of shore to bend a bay, brings us by commodius vicus of recirculation back to Howth Casle and Environs (Joyce, 2000, p. 3).

Translation of A. Volokhonsky:

Beg reki mimo Evy s Adamom, ot beroj izluchiny do izgiba zaliva prostornym prostranstvom vozvratnyh techenij prinosit nas vspjat' k zamku Haut i ego okrestnostjam (Joyce, 200oa, p. 7).

Translation of H. Beck:

flusslauf, vorbei an Ev' and Adams, vom küstenknick zum bug der bucht, bringt uns auf 
kommodem vicus zirkel wieder zurück zu Howth Castells Engrer umgebung (Joyce, 1989, p. 27).

Translation of K. Jauslin:

Flu $\beta$ flo $\beta$ furbay Eva' und Adams dahein, vom Klippenrand zur verschlungenen Bucht, und er bringt uns wieder in lässigem Circel zurück über Commodus und Vico nach Hoth Castle samt Einzugskreis (Joyce, 1989, p. 36).

Translation of W. Schrödter:

Flußeslauf, Seit' Eve und Adams, von der Krümmung der Küste zur Biegung der Bucht, bringt uns in einem commoden Rezirkulus viciosus zurück zu Howth Castle and Ergebungen (Joyce, 1989, p. 38).

Translation of F. Rathjen:

Flußgefließe, schleunigst Ev' und Adam passiert, vom Strandgestreun zum Buchtgebeug, führt uns im commundiösen Wickelwirken des Rezirkulierens zurück zur Burg von Howth con Entourage (Joyce, 1989, p. 44).

We have already mentioned about preserving cyclic effect by means of isolating the article from the noun to break the sentence. In addition to this stylistic device, complexity effect and spacetime unity are achieved in the excerpt by foreign words embedded in the text as barbarisms. Particularly, these are "commodious", "vicus" and "reciculation" lexemes originating from Latin. A. Volokhonsky renders this phrase ("by comodius vicus of recirculation") by descriptive translation ("prostornym prostranstvom vozvratnyh techenij") based on individual associative interpretation of ST (cf. literal translation of constituent components of the given wordcombination: Lat. "commodius" - more comfortable, favorable; Lat. "vicus" - village; Lat. "recirculation" - resumption of circulation). Wordplay in "vicus" and "recirculation" expressed in a word-combination with similar sounds "vicious circle" is not rendered in TL.

German translator H. Beck renders the word-combinations as: "bringt uns auf kommodem vicus Zirkel wieder". Only one Latin barbarism is left ("vicus"). ST lexeme "commodius" is substituted by a colloquially connotated Austriazism "kommod" (comfortable, calm), and "recirculation" is conveyed by a German equivalent with identical semantics. Thus, a flavor of foreignness and intricacy is preserved though partial translation of Barbarism and makes the text more comprehensive.

Analyzing the same passage in translation of K. Jauslin, we can see: "bringt uns wieder in lässigem Circel zurück über Commodus und Vico". The main ST lexeme "commodious" is split into implicit and explicit planes verbalized in the text. Thus, we have a highly subjectivized German version: the translator identifies SL word-combination "commodius vicus of recirculation" as sounding similar to Latin set expression "circulus vitiosus" (vicious circle), and conveys the idea of time cycle. It forms the basis of Finnegans Wake by Joyce and originates from the idea of cyclical nature of history by a medieval philosopher G. Vico, whose name is referred to in the novel thus expressing J. Joyce's implicit hint. The second proper name - the one of Roman Emperor Commodus - correlates with the structure and the plot of the novel even less. Presumably, the translator reflects on the end of the Emperor's rule, which came from a wellknown ruling dynasty, and the beginning of a new cyclical period in the state. Spelling of a German word "Circel" evokes reminiscences of Greek goddess of magic Circe in a way of impersonation and transformation. Originally, it reinforces the idea of time cycles. Besides, connotations associated with Circe, which turns lovers into swine, add a shade of disapproval and 
admission of perversity of love joys to TT, though it is missing in ST in our view.

Another German translator W. Schrödter focuses on insularity of time-space unity and eternal return to origins. This version presents "commodius vicus of recirculation" in a more equivalent way "in einem commoden Rezirkulus viciosus", where the first two components are rendered in German. The time-space "vicious cycle" is emphasized whereas the river flow by the village is set in the background.

The final analyzed version of translation of the first passage from Finnegans Wake by Joyce is the rendered by F. Rathjen. The part in consideration is even more assimilated with German morphological system, which is manifested by suffixes in "commundiös" and "Rezirculierens". A foreign shade, pursuit of confusion and nonsense is conveyed by stylistic compensation: omitted Latin words are compensated by a French Barbarism "Entourage" ("surroundings"). Space cyclical nature of time in world history is emphasized in TT by "commundiös" (Cf. similar sounding Latin "com" - together and "mundus" - world, universe).

\section{Conclusion}

The given examples allow to conclude the importance of hermeneutic aspect in translation activity when rendering modernism text in general and SCT in particular. Dominant space-time linearity (first type SCT) and cyclic nature and inconsistency (second type SCT) can be conveyed in a communicatively equivalent way in TL, still complete translation equivalence in sense overtone preservation is hardly probable. Translation of first type SCT features mostly literal hyperlinear equivalents (equivalents or transcribed SL lexemes), whereas the translation of second type SCT conveys hermeneutic reflection of a translator being in search of the most adequate way of form generation which renders multidimentional sense of the author's intentions to the greatest extent possible.

The prospective of studying SCT text in translation aspect falls within the following scope:

- Study of equivalence in translated versions of SCT by particular writers with account of gender and age peculiarities of their language persona;

- Studies of actualization and rendering of intertextual passages in different types of SCT chronotopes;

- Studies of SCT perception in SL and TT.

Generally, such research will allow us to study the structure and functions of SCT in SL and TL as the addressers and addressees come from different linguocultures.

\section{References}

Bakhtin, M. (200o). Forms of Time and of Chronotope in the Novel. In Bakhtin, M. The Epic and Novel. St. Petersburg: Azbuka.

Breus, E. V. (2003). The Theory and Practice of Translation (English-Russian). Moscow: RAO Publishing. 
Catford, J. C. (1965). A Linguistic Theory of Translation: An Essay in Applied Linguistics. London: Oxford University Press.

Chatman, S. (1980). Story and discourse: Narrative structure in fiction E film. New York: Cornell University Press.

Childs, P. (2000). Modernism. London \& New York: Routledge.

Galperin, I. R. (2006). Text as an Object of Linguistic Research. Moscow: URSS.

Joyce, J. (2007). OdissejJa (S. Makhov Trans.). Moscow: SFK Invest.

Joyce, J. (2000). Finnegans Wake. London: Penguin Books.

Joyce, J. (200oa). Finnegans Wake. (A. Volokhonsky Trans.).Tver: KOLONNA.

Joyce, J. (1989). Finnegans Wake Deutsch. Gesammlte Annäherungen. Hrsg. R. Reichert und F. Senn. Frankfurt am Main: Suhrkamp.

Joyce, J. (200ob). Ulysses. London: Penguin Books.

Joyce, J. (1966). Ulysses. (G. Goyert Trans.). München: Deutscher Taschenbuchverlag.

Joyce, J. (2004). Ulysses. (V. Khinkis and S._Khoruzhii Trans.). St. Petersburg: Azbuka.

Joyce, J. (2006). Ulysses. (H. Wollschläger Trans.). Frankfurt am Main: Suhrkamp.

Kade, O. (1968). Zufall und Gesetzmäßigkeit in der Übersetzung. Leipzig: VEB Verlag Enzyklopädie.

Koller, W. (1979). Einführung in die Übersetzungswissenschaft. Heidelberg \& Wiesbaden: Quelle und Meyer.

Mc Hugh, R. (1991). Annotations to Finnegans Wake. Baltimore: John Hopkins University Press.

Nida, E. A. and Ch. Taber (1982). The Theory and Practice of Translation. Leiden: E. J. Brill.

Pym, A. (2007). Natural and Directional Equivalence in Theories of Translation. Target, 19:2, 271-294.

Reis, K. (1976). Texttypen, Übersetzungstypen und die Beurteilung von Übersetzungen. Lebende Sprachen, 22:3. 97-100.

Steinberg, E. R. (1982). The Stream-of-Consciousness Technique in the Novel: Simulating a Stream of Concurrencies. Imagination, Cognition and Personality, vol. 2(31), 241 -249.

Toury, G. (1980). In Search of a Theory of Translation. Tel Aviv: Porter Institute for Poetics and Semiotics.

Vinogradov, V. S. (2001). An Introduction to Translation Studies. Moscow: RAO Publishing.

Alexandra Milostivaya is Associate Professor at the North-Caucasus Federal University (Russia). She teaches such subjects as Practical Course of Translation, Language Typology, Theory of Translation. Within the scope of her scientific interests are semiotics, translation studies and intercultural communication.

Irina Makhova is Associate Professor at the Stavropol State Agrarian University (Russia). She teaches such subjects as Practical Course of Translation and Practical Course of Oral Communication. Within the scope of her scientific interests are semantics, translation studies and intercultural communication. 